\title{
COMBINATION OF FUZZY-AHP AND DEMATEL-ANP WITH GIS IN A NEW HYBRID MCDM MODEL USED FOR THE SELECTION OF THE BEST SPACE FOR LEISURE IN A BLIGHTED URBAN SITE
}

\author{
Ahmad POURAHMAD ${ }^{\mathrm{a}}$, Ali HOSSEINI ${ }^{\mathrm{a}}$, Audrius BANAITIS ${ }^{\mathrm{b}}$, Hossein NASIRIc, \\ Nerija BANAITIENË $\dot{b}^{\mathrm{b}}$, Gwo-Hshiung TZENG ${ }^{\mathrm{d}}$ \\ ${ }^{a}$ Department of Geography and Urban Planning, University of Tehran, 1417854151 Tehran, Iran \\ ${ }^{b}$ Department of Construction Economics and Property Management, Faculty of Civil Engineering, \\ Vilnius Gediminas Technical University, Sauletekio al. 11, 10223 Vilnius, Lithuania \\ ${ }^{c}$ Department of Human Geography, University of Tehran, 1417854151 Tehran, Iran \\ ${ }^{d}$ Graduate Institute of Urban Planning, College of Public Affairs, National Taipei University, Taiwan
}

Received 22 March 2015; accepted 10 May 2015

\begin{abstract}
Urban blight issues have transformed over time. Today, the focus is on the social context and such services as recreation and leisure. Considering that the insufficiency of leisure spaces in blighted urban neighbourhoods gives rise to social and cultural problems in Tehran, this research aims to identify the best leisure space in a blighted urban site. The selection process uses the combination of a new hybrid MCDM model and GIS. The integration of GIS and MCDM makes a powerful tool for the selection of the best leisure space in a site because GIS provides efficient manipulation, analysis and presentation of spatial data while MCDM supplies consistent weight of sub-criteria and criteria. The results show the interrelations between dimensions and criteria, also influential priorities and the most important sequences of those. Afterward, this study employs DANP to obtain the weight of each criterion and select a site for leisure using GIS, based on INRM from the DEMATEL method.
\end{abstract}

Keywords: leisure space, urban blight, hybrid multiple criteria decision making (HMCDM), influential network relation map (INRM), geographic information system (GIS).

JEL Classification: C02, C44, C61, C88, O18, O21, O35, R14.

\section{Introduction}

Leisure is a variety of activities that people engage in after work, away from their family and community to rest, have fun as well as develop information, non-profit education, and community partnerships (Torkildsen 2005). To express its importance, leisure is portrayed

Corresponding author Audrius Banaitis

E-mail: audrius.banaitis@vgtu.lt 
by researchers as a cultural mirror of society and re-socialization. That is, cultural existence and identity are based on the amount of time allocated for leisure for the enjoyment of a member of society. Pieper (2009) stated that culture existence and authenticity are based on the leisure time of people who live in the society. Development and creation of leisure spaces not only provides convenience, comfort and improved quality of life of citizens (Henderson 2007). It also plays a role in protection of the environment and sustainable development through a hierarchy of different designs (Thibault 2011), considering the real needs and possibilities (Willemse, Donaldson 2012), interactions (Konlaan et al. 2002), the participation of effective factors (Stebbins 2013) and influences factors that impact on the views of users of these sites (Genoe 2010).

Many studies in the field of leisure and leisure spaces are done based on social, behavioural or geographical points of view (Cheng, Tsaur 2012; Craig, Mullan 2012; Harinen et al. 2012). Fewer research efforts deal with the topic of location, which requires holistic observation, flexibility and the use of quality and quantity indexes in predicting required parcels of land, their distribution and the composition of different uses.

Selection of spaces appropriate for leisure requires the consideration of multiple factors. The vastness and complexity of factors that affect localization necessitate the use of GIS in combination with MCDM. The potential advantage of a GIS-based approach for siting arises from the fact that it not only reduces the time and cost of site selection but also provides a digital data bank for long-term monitoring of the site (Moeinaddini et al. 2010). The analysis of leisure space siting can be improved and facilitated with the help of GIS. GIS is an appropriate tool for site selection due to its capability to manage large volumes of geographic or spatial data from several sources. In recent years, interest in the fusion of MCDM and GIS has significantly increased. The use of MCDM and knowledge of experts for further exploitation of the GIS potential led to optimised spatial decision making (Sánchez-Lozano et al. 2013). MCDM methods attempt to improve the quality of decisions through clearer, more reasonable and more efficient decision processes (Liu et al. 2012; Peng, Tzeng 2013). Therefore, the main objective of the integration of GIS and MCDM is to facilitate decision making in site selection.

Often, studies based on GIS and MCDM methods are focused on the selection or evaluation of locations suitable for certain natural environment issues and regional planning. However, less consideration is given to urban leisure planning. Therefore, we propose a new hybrid model of Suitable Zones for Creative Development (SZCD), which is based on MCDM in GIS environment. The model can be used for exploring blighted urban sites in search of the best space for leisure. In this study, FAHP, ANP, and DEMATEL were used in combination with GIS to identify locations appropriate for the development of leisure spaces in Gheytariyeh neighbourhood of Tehran. To quantifying the subjective judgment concerning the uncertainty in the decision-making stage, FAHP method was applied to determine the value of each sub-criteria. The DEMATEL method was used to determine the relationships among the criteria; and ANP method was used to measure them based on relationships specified by DEMATEL. The proposed method can be useful for urban planners aiming to locate, plan and allocate resources for spaces appropriate for leisure in urban settings. 


\section{Literature review}

Leisure has a positive impact on individual's growth and social connections. This means that some changes occur in ideas, values and skills of an individual engaged in different activities during the time allocated for leisure. In fact, there are potential advantages of leisure activities conducted in partnership with others. These advantages include self-confidence, spiritual growth, learning, and creativity. Dumazedier and McClure (1967) argued that the increase in talent and creativity of an individual is the purpose and result of leisure activities. Leisure time provides opportunities for individuals to release their energy in a group activity of a certain field or domain and achieve creativity and efflorescence (Tan et al. 2014; Van Holm 2014). One of the main problems with creativity is its definition. In summary, previous scientific research on creativity defines it as the subjective judgment of novelty and the appropriateness of products to generate the development of new and useful ideas and techniques, novel procedures or innovative approaches to performing a job improvement (Horng et al. 2013b).

According to Sternberg (2006), the analysis of human intellectual abilities is impossible without the consideration of the background, conditions and the place, in which it operates. The place must encourage innovation and creativity. This can be achieved by: ensuring participative safety, encouraged challenging of assumptions and perceptions, visioning, resources, freedom, unity and cooperation, encouraged atmosphere of enjoyment and fun, engaging people in planning and decision-making, and establishing a space for excellence (McFadzean 1998; Wong, Pang 2003). Richards (2011) suggested that various strategies can be created including the creative cities and the creative class to use distinctive places for the growth of creative approaches to tourism (and leisure).

Plans for the renovation of blighted urban spaces have certain characteristics, including the development of potentially creative power in the form of popular art, the construction of cultural structure, the abundance of street cafes and nightclubs, and flourishing industries and cultural arts (Rabbiosi 2015). Blighted urban sights emerge over time and usually lack spaces for leisure. Established leisure spaces can facilitate creative approaches to reduction of crime through festivals, concerts at noon, art exhibitions, and street theatre. Also, this could lead to economic growth and welfare through physical rehabilitation of buildings of high architectural value in modern spaces with functions that attract tourists and contribute to cultural exchange between different neighbourhoods of the city.

Creative development is defined as available actual and potential capacities and abilities to achieve a desirable situation. It turns an urban site, which is blighted in social, economic and physical terms, into a high quality and desirable situation that provides residents with access to urban, social and leisure services. The factor affecting the creative development of leisure spaces in blighted urban sites is extracted from appropriate knowledge on urban renovation components. 


\section{Methodology}

\subsection{Fuzzy AHP}

The Analytic Hierarchy Process (AHP) is broadly used in MCDM research. In AHP, the calculation method proposed by Saaty (1980) was based on crisp judgment. However, in the real world, it is very difficult to extract precise data pertaining to measurement factors since all human preferences are prone to a degree of uncertainty (Zavadskas et al. 2014). Decision-makers (DM) are also inclined to favour natural language expressions over exact numbers when assessing criteria and alternatives (Heo et al. 2010; Hsueh et al. 2013; Tan et al. 2014). For this reason, FAHP methods, which effectively resemble human thoughts and perceptions, were systematically proposed by various authors.

This section of the study employed the trapezoidal fuzzy numbers approach to gain a weight estimation, which incorporates the fuzzy set theory into AHP while dealing with the linguistic term measures in a questionnaire survey. FAHP is implemented in steps (Mentes, Helvacioglu 2012; Wang et al. 2006). First, assign linguistic terms to pairwise comparisons by asking, which is the more important of each two dimensions, as in the following matrix A (Sun 2010) (Eq. 1):

$$
A=\left[\begin{array}{cccc}
1 & a_{12} & \ldots & a_{1 n} \\
a_{21} & 1 & \ldots & a_{2 n} \\
\vdots & & & \\
a_{n 1} & a_{n 2} & \ldots & 1
\end{array}\right]=\left[\begin{array}{cccc}
1 & a_{12} & \ldots & a_{1 n} \\
\frac{1}{a_{21}} & 1 & \ldots & a_{2 n} \\
\vdots & & & \\
\frac{1}{a_{n 1}} & \frac{1}{a_{n 2}} & \ldots & 1
\end{array}\right] .
$$

The geometric mean of each row is calculated as follows (Eq. 2):

$$
Z_{i}=\left[\prod_{j=1}^{n} a_{i g}\right]^{\frac{1}{n}} \text { for } j, k=1,2, \ldots, n .
$$

The weight element $W_{i}$ is constructed as follows (Eq. 3):

$$
W_{i}=\frac{Z_{i}}{\left(Z_{1}+Z_{2}+\ldots+Z_{n}\right)}, \forall_{i} .
$$

To facilitate the calculation of fuzzy weights, the following arithmetic operations of trapezoidal fuzzy number (TFN) are presented. A TFN can be defined as $\tilde{M}_{1}=(a ; b ; c ; d)$ where $0 \leq a \leq b \leq c \leq d$ its membership function is as follows (Eq. 4):

$$
\mu_{\tilde{Q}}(x)=\left\{\begin{array}{cc}
0 & \text { if } x \leq a \text { or } \geq d \\
1 & \text { if } b \leq x \leq c \\
a \in[0.1] & \text { if } a \leq x \leq b \\
a \in[0.1] & \text { if } c \leq x \leq d
\end{array} .\right.
$$


Let $\tilde{M}_{1}=\left(a_{1}, b_{1}, c_{1}, d_{1}\right)$ and $\tilde{M}_{2}=\left(a_{2}, b_{2}, c_{2}, d_{2}\right)$ be two TFNs. Some main operations of fuzzy numbers $\tilde{M}_{1}$ and $\tilde{M}_{2}$ can be expressed as follow (Eqs 5-9) (Chen et al. 2006):

$$
\begin{gathered}
\tilde{M}_{1}+\tilde{M}_{2}=\left(a_{1}+a_{2}, b_{1}+b_{2}, c_{1}+c_{2}, d_{1}+d_{2}\right) ; \\
\tilde{Q}=\tilde{M}_{1} \times \tilde{M}_{2}=\left(a\left[L_{1}, L_{2}\right], b, c, d\left[R_{1}, R_{2}\right]\right) ; \\
a=a_{1} a_{2}, b=b_{1} b_{2}, c=c_{1} c_{2}, d=d_{1} d_{2} ; \\
L_{1}=\left(b_{1}-a_{1}\right)\left(b_{2}-a_{2}\right), L_{2}=a_{2}\left(b_{1}-a_{1}\right)+a_{1}\left(b_{2}-a_{2}\right) ; \\
R_{1}=\left(d_{1}-c_{1}\right)\left(d_{2}-c_{2}\right), R_{2}=-\left[d_{2}\left(d_{1}-c_{1}\right)+d_{1}\left(d_{2}-c_{2}\right)\right] .
\end{gathered}
$$

To defuzzify the TFN $\tilde{M}_{1}=\left(a_{1}, b_{1}, c_{1}, d_{1}\right)$, the following (Eq. 10) can be calculated:

$$
Z^{*}=\frac{\int \mu_{\tilde{c}}(z) \cdot z d z}{\int \mu_{\tilde{c}}(z) d z} .
$$

The steps of the FAHP algorithm can be summarized as follow:

Step 1. Each expert made an evaluation for the relative importance of the sub-criteria using pairwise comparisons. The experts denoted their judgments based on their experience and knowledge. The questionnaire was prepared based on pairwise comparison using linguistic terms (Table 2).

Step 2. The aggregation is performed by applying the fuzzy weighted trapezoidal averaging operator (Sun 2010) (Eq. 11):

$$
\tilde{X}_{i k}=\frac{1}{K}\left[\tilde{X}_{i k}^{1} \otimes \tilde{X}_{i k}^{2} \otimes \ldots \otimes \tilde{X}_{i k}^{k}\right] .
$$

Eq. (11) was calculated to obtain the aggregation of the linguistic terms. Where $K$ is the number of experts and $\tilde{X}_{i}^{k}$ is the evaluation of the $K^{\text {th }}$ decision-maker regarding the pairwise importance comparison of $i^{\text {th }}$ and $k^{\text {th }}$ criteria.

Step 3. Determine the fuzzy weights $\tilde{W}_{i}$. The derivation of $\tilde{Z}_{i}$ values (Eq. 2) and fuzzy weights $\tilde{W}_{i}$ (Eq. 3) can be detailed as follows (Eqs 12 and 13). Let:

and

$$
a_{i}=\left[\prod_{j=1}^{n} a_{i j}\right]^{1 / n}
$$

$$
a=\sum_{i=1}^{m} a_{i}
$$

Similarly, we can define $b_{i}$ and $\mathrm{b}, c_{i}$ and $c$, and $d_{i}$ and $\mathrm{d}$. Then, the fuzzy weight $\tilde{A}$ is obtained as (Eq. 14) (Chen et al. 1992):

$$
\tilde{W}_{i}=\left(\frac{a_{i}}{d}, \frac{b_{i}}{c}, \frac{c_{i}}{b}, \frac{d_{i}}{a}\right) .
$$

Step 4. Defuzzification is a mathematical process performed to convert fuzzy output into a crisp value. Some of the common defuzzification techniques include maximum membership principle, weighted average method, mean-maximum membership (Ross 2009), use of 
inflection points (Sicat et al. 2005), and Centroid of Area (COA) (Reshmidevi et al. 2009). In the present study, the COA method was applied for the defuzzification process. The advantage of the COA method is that all activated membership functions of the conclusions (all active rules) take part in the defuzzification process (Daftaribesheli et al. 2011). The COA method applies the following Eq. (15) to transfer a fuzzy scheme into a crisp value (Iphar, Goktan 2006; Zheng et al. 2012):

$$
Z^{*}=\frac{\int \mu_{\tilde{c}}(z) \cdot z d z}{\int \mu_{\tilde{c}}(z) d z},
$$

where $Z^{*}$ is the crisp value for the " $z$ " output and $\grave{i}_{\tilde{c}}(z)$ is the aggregated output membership function.

\subsection{The DEMATEL technique}

The Decision Making Trial and Evaluation Laboratory (DEMATEL) was developed between 1972 and 1976 by the Science and Human Affairs Program of the Battelle Memorial Institute of Geneva (Fontela, Gabus 1976; Gabus, Fontela 1972). It is especially practical and useful for visualizing the structure of complicated causal relationships with matrices or digraphs. The methodology, according to the concrete characteristics of objective affairs, can confirm interdependence among criteria and restrict the relationships that reflect characteristics within an essential systemic and developmental trend (Hsu et al. 2012).

The matrices portray a contextual relationship between the elements of the system, in which a numeral represents the strength of the influence. Hence, the DEMATEL technique is used to research and solve complicated, intertwined problems and to build and analyse an intelligible structural model that involves causal relationships between criteria. In essence, the DEMATEL technique supposes that a system contains a set of criteria $C=\left\{C_{1}, C_{2}, \ldots, C_{n}\right\}$ and the particular pairwise relationships are determined for modelling with respect to a mathematical relationship (Horng et al. 2013a).

Below, steps for the solution process are described.

Step 1. Calculate the initial average matrix. Suppose we have $H$ experts in this study and $n$ criteria to consider. The pairwise comparison scale that measures the relationship between any two criteria should be designated across five levels, where the integer scores ranging from 0 to 4 represent "no influence (0)"; "low influence (1)"; "medium influence (2)"; "high influence (3)" and "very high influence (4)" respectively. Experts were asked to indicate the degree of direct influence that each criteria $i$ exerts on each criteria $j$, which is denoted by $a_{i j}$, using the assumed scales.

The scores by each expert will give us a $n \times n$ non-negative answer matrix, $X^{k}=\left[X_{i j}^{k}\right] n \times n$ with $1 \leq k \leq H$. Thus, $\boldsymbol{X}^{1}, \boldsymbol{X}^{2}, \ldots, \boldsymbol{X}^{H}$ are the answer matrices for each of the $H$ experts, and each element of $X^{k}$ is an integer denoted by $x_{i j}^{k}$. The diagonal elements of each answer matrix $X^{k}$ are all set to zero. We can then compute the $n \times n$ average matrix $A$ for all expert opinions by averaging the $H$ experts' scores as follows (Eq. 16):

$$
\left[a_{i j}\right]_{n \times n}=\frac{1}{H} \sum_{k=1}^{H}\left[x_{i j}^{k}\right]_{n \times n} .
$$


Step 2. Normalizing the direct-relation matrix. Calculate the initial direct influence matrix. The initial direct influence matrix $D$ (i.e., $D=\left[d_{i j}\right]_{n \times n}$ can be obtained by normalizing the average matrix $A$. In addition, the matrix $D$ can be obtained through Eqs. (17) and (18), in which all principal diagonal criteria are equal to zero.

$$
S=\operatorname{Min}\left(\frac{1}{\max _{1 \leq i \leq n} \sum_{j=1}^{n}\left[a_{i j}\right]}, \frac{1}{\max _{1 \leq j \leq n} \sum_{i=1}^{n}\left[a_{i j}\right]}\right) .
$$

Step 3. Attaining the total-relation matrix. Once the normalized direct-influence matrix $D$ is obtained, the total-influence matrix $T$ of influential network relation map (INRM) can be obtained through Eq. (19), in which $I$ denotes the identity matrix.

$$
\begin{gathered}
T=D+D^{2}+D^{3}+\ldots+D^{k}=D\left(I+D+D^{2}+\ldots+D^{k-1}\right)\left[(I-D)(I-D)^{-1}\right]= \\
\quad D\left(I-D^{k}\right)(I-D)^{-1} . \\
\text { Then } T=D(I-D)^{-1} \text {, when } k \rightarrow \infty, D^{k}=[0]_{n \times n} .
\end{gathered}
$$

Step 4. Compute dispatcher group and receiver group. The $D$ vector $\left(c_{i}, \ldots, c_{j}, \ldots, c_{n}\right)^{\prime}$ presents the sum of the rows of matrix $T$, and is the sum of the influences dispatching from element $i$ to the other element. The vector $r=\left(r_{i}, \ldots, r_{j}, \ldots, r_{n}\right)^{\prime}$ presents the sum of the columns of matrix $T$, a level of influence to others and a level of relationship with others are defined, as shown in Eqs (20)-(22). Where $r_{i}$ denotes the row sum of the $i^{\text {th }}$ row of matrix $T$ and shows the sum of total effects, both direct and indirect effects, of factor/criteria $i$ on the other factors/criteria. Similarly, $c_{j}$ denotes the column sum of the $j^{\text {th }}$ column of matrix $T$ and shows the sum of total effects, both direct and indirect effects, that factor/criteria $j$ has received from the other factors/criteria. Additionally, $r_{i}+c_{j}$ provides an index of the strength of influences total sum of effects both given and received when $i=j$, that is, $r_{i}+$ $c_{j}$ shows the degree of importance role that criteria $i$ plays in the problem. In addition, the difference $\left(r_{i}-c_{j}\right)$ shows the net effect that criteria $i$ contributes to the problem. If $r_{i}-c_{j}$ is positive, then factor $i$ is affecting other factors, and if $r_{i}-c_{j}$ is negative, then factor $i$ is being influenced by other factors.

$$
\begin{gathered}
T=\left[t_{i j}\right]_{n \times n}, i, j=1,2, \ldots, n ; \\
r=\left[\sum_{j=1}^{n} t_{i j}\right]_{n \times 1}=\left[t_{i}\right]_{n \times 1}=\left(r_{i}, \ldots, r_{j}, \ldots, r_{n}\right)^{\prime} ; \\
c=\left[\sum_{i=1}^{n^{\prime}} t_{i j}\right]_{1 \times n}=\left[t_{j}\right]_{n \times 1}=\left(c_{i}, \ldots, c_{j}, \ldots, c_{n}\right)^{\prime} .
\end{gathered}
$$

Step 5. Set the threshold value and obtain the influential network relation map (INRM). Setting a threshold value to filter the obvious effects denoted by the factors of matrix $T$, 
is necessary to explain the structure of the factors. Based on the matrix $T$, each factor $t_{i j}$ of matrix $T$ provides network information on how factor $i$ affects factor $j$. The threshold value is decided by the decision-maker or by experts through discussion. Only some criteria, whose effect in matrix $T$ is higher than the threshold value, should be chosen and converted in a INRM for influence. An INRM can be obtained by mapping the dataset of $(D+R, D-R)$, where the horizontal axis $D+R$, and the vertical axis $D-R$ (Wu, Lee 2007).

\subsection{The DANP method}

Since the evaluation of SZCD involves complex criteria that have dependent relationships, the ANP method must be applied. The decision-making process cannot always be described by a hierarchy of decision problem elements organised as goal, criteria, and alternatives. Therefore, the interactions and feedback dependencies between the elements of the decision problem at the same or different levels of hierarchy must be taken into consideration (Tsai, Kuo 2011). Saaty (1980) developed the ANP for decision-ranking priorities without making assumptions about a unidirectional hierarchical relationship among decision levels. ANP handles dependence and feedback within a cluster (inner dependence) and among different clusters (outer dependence). So, the ANP has a nonlinear structure containing a goal at the top level and criteria at the bottom level (Chen et al. 2011; Liou 2012; Liou et al. 2011; Lin, Pan 2014). In addition, this method calculates the relative weightings (eigenvectors) of each rule.

The DEMATEL technique is not only used to construct the interaction relationship between each factor/criteria but also to obtain the most accurate weights of influence. The traditional ANP solves the problems with interdependence and feedback only on aspects (or called dimensions), factors/criteria until to be independent. Therefore, we use these basic ANP concepts (Saaty 1996) as a base and combine them with the DEMATEL to solve these issues (interdependence, not only aspects, but also all criteria). All of the interactions between the elements on clusters are evaluated using pairwise comparisons, when building the structure of the problem. The DEMATEL technique can be used to build the network relationship map for objectively constructing super-matrix. Therefore, the important step of ANP is to compare the criteria in whole systems to form the super-matrix through pairwise comparisons. Another question is how much importance of a criteria has compared with another criteria with respect to the interests or preferences of experts (Karsak et al. 2003). The relative importance can be determined using a scale of 1 to 9 , representing a range from equal, moderately, strongly, very strongly (1, 3, 5 and 7 respectively), to extreme importance (9) and importance of 2, 4, 6, and 8 as the intermediate importance for the preference scale (Chen et al. 2010; Liou 2012; Saaty 1980, 1996; Shen et al. 2011; Yazdani-Chamzini 2014; Gudienè et al. 2014; Kaya, Kahraman 2014). Finally, after the computation of the relationship of the super-matrix and the comprehensive evaluations, it is possible to derive the interdependence of each valuation criteria and options and the weighting of priorities. The higher the priority weightings, the more priority will be placed (Tsai, Chou 2009).

The influential weights of DANP (DEMATEL-based ANP) contains the following steps. 
Step 1. Model construction and problem structure. The elements in a cluster can interact with some or all of the elements of another cluster. Also, relationships among elements in the same cluster can exist (Lee et al. 2012; Lee, Tu 2011). It can be generated based on DM and expert opinions that are collected through brainstorming, focus groups, interviews, etc. (Tsai, Kuo 2011).

Step 2. Establish the unweighted super-matrix. The total-influence matrix $T$ shown in Eq. (23) is received from DEMATEL. Each column will be summed up for normalization.

$$
\begin{aligned}
& \begin{array}{lll}
D_{1} & D_{j} & D_{n}
\end{array} \\
& c_{11} \cdots c_{1 m_{1}} \cdots c_{j 1} \cdots c_{j m_{j}} \cdots c_{n 1} \cdots c_{n m_{n}}
\end{aligned}
$$

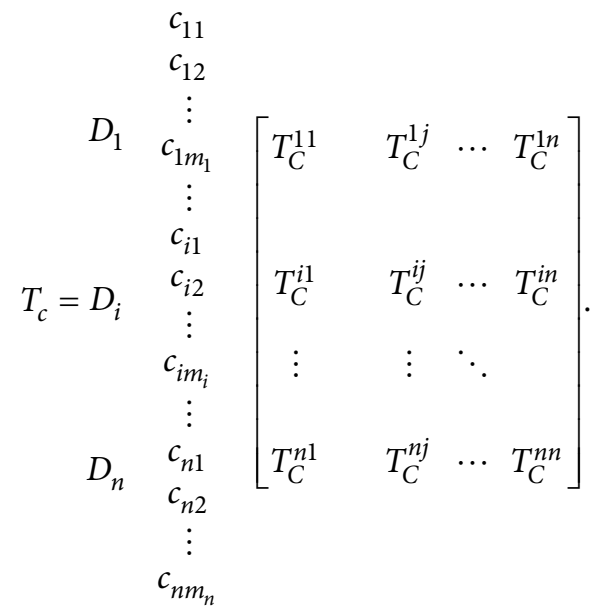

After normalizing the total-influence matrix $T_{C}$ by dimensions (clusters), we will obtain a new matrix $T_{C}^{\alpha}$, shown as Eq. (24).

$$
\begin{aligned}
& D_{1} \quad D_{j} \quad D_{n} \\
& c_{11} \cdots c_{1 m_{1}} \cdots c_{j 1} \cdots c_{j m_{j}} \cdots c_{n 1} \cdots c_{n m_{n}} \\
& c_{12}
\end{aligned}
$$

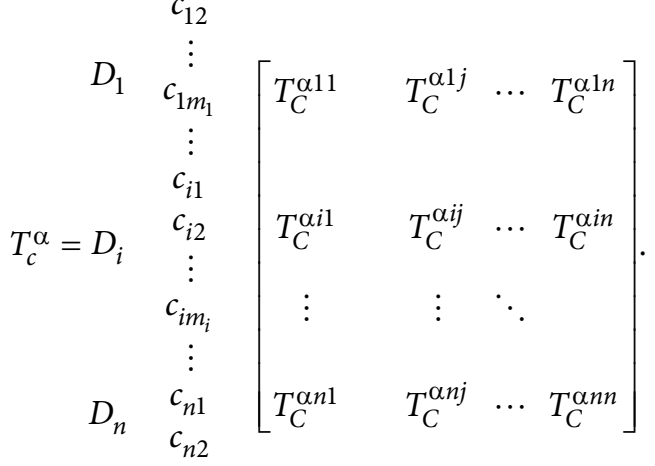

$$
\begin{aligned}
& c_{n m_{n}}
\end{aligned}
$$

where $T_{C}^{\alpha 11}$ is obtained as Eqs (25)-(26), and other $T_{C}^{\alpha n m}$ values are as above. 


$$
\begin{gathered}
d_{c i}^{11}=\sum_{j=1}^{m 1} t_{c i j}^{11}, i=1,2, \ldots, m 1 ; \\
T_{C}^{\alpha 11}=\left[\begin{array}{ccccc}
t_{C 11}^{11} / d_{C 1}^{11} & \cdots & t_{C 1 j}^{11} / d_{C 1}^{11} & \cdots & t_{C 1 m_{1}}^{11} / d_{C 1}^{11} \\
\vdots & & \vdots & & \vdots \\
t_{C i 1}^{11} / d_{C i}^{11} & \cdots & t_{C i j}^{11} / d_{C i}^{11} & \cdots & t_{C i m_{1}}^{11} / d_{C i}^{11} \\
\vdots & & \vdots & & \vdots \\
t_{C m_{1} 1}^{11} / d_{C 1}^{11} & \cdots & t_{C m_{1} j}^{11} / d_{C m_{1}}^{11} & \cdots & t_{C m_{1} m_{1}}^{11} / d_{C m_{1}}^{11}
\end{array}\right]=\left[\begin{array}{ccccc}
t_{C 11}^{\alpha 11} & \cdots & t_{C 1 j}^{\alpha 11} & \cdots & t_{C 1 m_{1}}^{\alpha 11} \\
\vdots & & \vdots & & \vdots \\
t_{C i 1}^{\alpha 11} & \cdots & t_{C i j}^{\alpha 11} & \cdots & t_{C i m_{1}}^{\alpha 11} \\
\vdots & & \vdots & & \vdots \\
t_{C m_{1} 1}^{\alpha 11} & \cdots & t_{C m_{1} j}^{\alpha 11} & \cdots & t_{C m_{1} m_{1}}^{\alpha 11}
\end{array}\right] .
\end{gathered}
$$

To acquire the unweighted super-matrix, use the interdependent relationship in the group to array $T_{C}^{\alpha}$ by dimensions (clusters), i.e., $W=\left(T_{C}^{\alpha}\right)^{\prime}$ (Eq. 27).

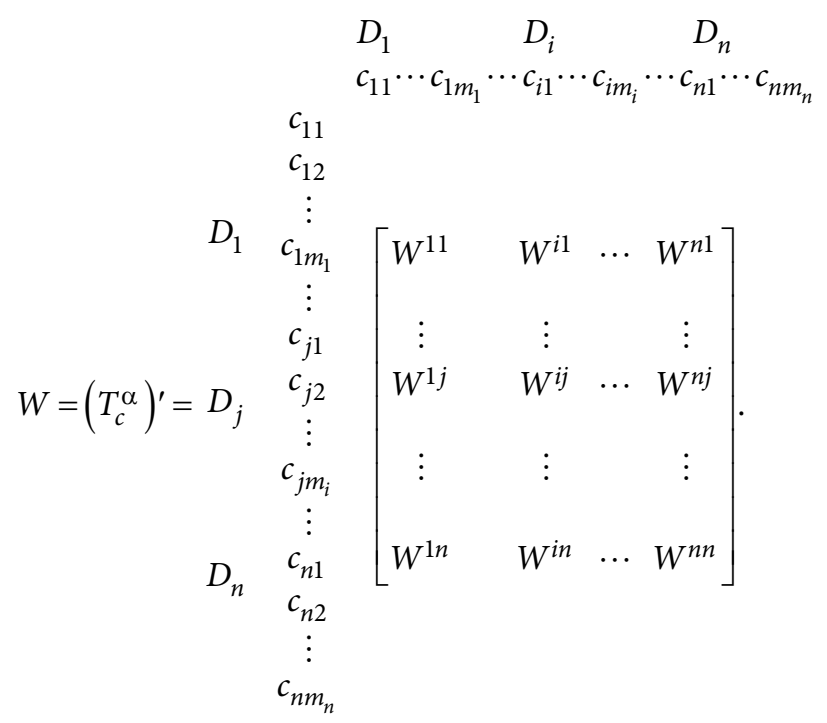

If the matrix $W^{11}$ is blank or 0 as shown in Eq. (28), this means that the matrix between the clusters or criteria is independent and with no interdependence, and the other $W^{n n}$ value is as given above.

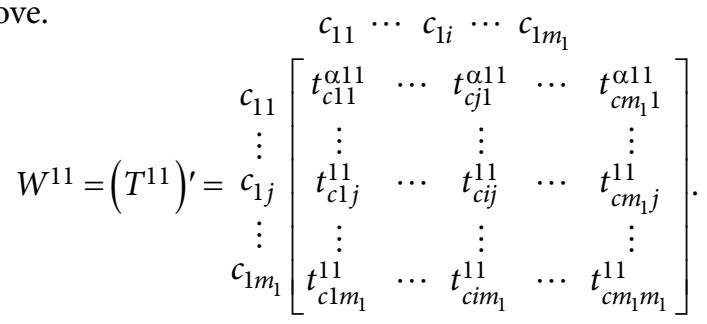

Step 3. Obtain the weighted super-matrix by normalizing the sum of impact for each hierarchy and each dimension in the dimensions total-influence matrix as illustrated in (Eq. 29).

$$
T_{D}=\left[\begin{array}{ccccc}
t_{D}^{11} & \cdots & t_{D}^{1 j} & \cdots & t_{D}^{1 n} \\
\vdots & & \vdots & & \vdots \\
t_{D}^{i 1} & \cdots & t_{D}^{i j} & \cdots & t_{D}^{i n} \\
\vdots & & \vdots & & \vdots \\
t_{D}^{n 1} & \cdots & t_{D}^{n j} & \cdots & t_{D}^{n n}
\end{array}\right] .
$$


Normalizing the total influence matrix $T_{D}$ yields $T_{D}^{\alpha}$ as follows (Eqs 30 and 31).

Where

$$
\left(T_{D}^{\alpha i j}=T_{D}^{i j} / d_{i}\right) \text {. }
$$

$$
T_{D}^{\alpha}=\left[\begin{array}{ccccc}
t_{D}^{11} / d_{1} & \cdots & t_{D}^{1 j} / d_{1} & \cdots & t_{D}^{1 n} / d_{1} \\
\vdots & & \vdots & & \vdots \\
t_{D}^{i 1} / d_{2} & \cdots & t_{D}^{i j} / d_{2} & \cdots & t_{D}^{i n} / d_{2} \\
\vdots & & \vdots & & \vdots \\
t_{D}^{n 1} / d_{3} & \cdots & t_{D}^{n j} / d_{3} & \cdots & t_{D}^{n n} / d_{3}
\end{array}\right]=\left[\begin{array}{ccccc}
t_{D}^{\alpha 11} & \cdots & t_{D}^{\alpha 1 j} & \cdots & t_{D}^{\alpha 1 n} \\
\vdots & & \vdots & & \vdots \\
t_{D}^{\alpha i 1} & \cdots & t_{D}^{\alpha i j} & \cdots & t_{D}^{\alpha i n} \\
\vdots & & \vdots & & \vdots \\
t_{D}^{\alpha n 1} & \cdots & t_{D}^{\alpha n j} & \cdots & t_{D}^{\alpha i n n}
\end{array}\right] .
$$

Let the normalized total-influence matrix fill into the unweighted super-matrix to obtain the weighted super-matrix (Eq. 32).

$$
W^{\alpha}=T_{D}^{\alpha} \times W=\left[\begin{array}{ccccc}
t_{D}^{\alpha 11} \times W^{11} & \cdots & t_{D}^{\alpha i 1} \times W^{i 1} & \cdots & t_{D}^{\alpha n 1} \times W^{n 1} \\
\vdots & & \vdots & & \vdots \\
t_{D}^{\alpha 1 j} \times W^{1 j} & \cdots & t_{D}^{\alpha i j} \times W^{i j} & \cdots & t_{D}^{\alpha n j} \times W^{n j} \\
\vdots & & \vdots & & \vdots \\
t_{D}^{\alpha 1 n} \times W^{1 n} & \cdots & t_{D}^{\alpha i n} \times W^{i n} & \cdots & t_{D}^{\alpha n n} \times W^{n n}
\end{array}\right] .
$$

Step 4. Limit the weighted super-matrix. Obtain the limited super-matrix, or the influential weight of each criteria, by multiple productions of the weighted super-matrix as $\lim _{\varphi \rightarrow \infty}=\left(W^{\alpha}\right)^{\varphi}$. That is to say, the influential weights of DANP are acquired by the limit super-matrix $W^{\alpha}$ with power $\varphi$, indicating any figure for power.

\section{An empirical case of the urban blight and old neighbourhoods of Tehran}

\subsection{Case study}

As one of the oldest neighbourhoods of Tehran with a long history, Gheytariyeh was one of peripheral villages of the capital. In time, it was gradually incorporated into the developing area of Tehran. The blighted area of the neighbourhood is the District 1, which is a part of the Tehran Municipality. Formation of the area triggered in 1946. In 1979, the neighbourhood was already rather developed and no free space was left undeveloped. The blight area of the neighbourhood remained intact until 2014. The only change was the increase of density in height and space. The neighbourhood covers the area of 4.85 hectares. The relative increase in density or the gross density of population is evident in the emergence of residential building blocks, with the top density amounting to 937 individuals per hectare. On street sides, there is only enough space to run a fast food business. In the long run, small businesses and shops have to change into a residential space. Considering the immense role of the residential use of the neighbourhood, strong community spirit among the locals as well as a great sense of enthusiasm for their neighbourhood, it is essential to solve the great shortage of leisure spaces in the neighbourhood and preserve its social identity (Pourahmad et al. 2012). 


\subsection{Data collection}

In the present study, snowball technique was used to determine the group of experts. In the process of collecting the questionnaires, experts were divided into two groups: Group A included managers and experts on leisure spaces and urban blight from the Tehran Municipality; Group B included academic experts. The groups were asked to express their opinions about the criteria for the selection of leisure spaces. The results of this questionnaire analysis contain the most important criteria for Stage 1 that comprise the basis of this research. Criteria were classified into four dimensions: Social (D1), Economic (D2), Built Environment (D3) and Management (D4) (Table 1). Data of these criteria were collected from the Tehran Municipality, the Statistic Centre of Iran. The total of 12 criteria were selected for Stage 1. Also, we used to complete the database through fieldwork.

The database layer was prepared for the modelling in GIS. The criteria included residence history (C12), number of floors (C31), oldness (C32), and the quality of buildings (C33) used in Stage 2. In Stage 3, Questionnaire FAHP for sub-criteria was prepared after the fieldwork based on trapezoidal fuzzy numbers. FAHP crisp weights of the sub-criteria were classified for each layer of criteria in the GIS environment. The results of Stage 1 were used and DANP was incorporated into the questionnaire design in Stage 4. In Stage 5, the most suitable site for leisure space in urban blight using GIS were selected (Fig. 1). 27 experts were asked to complete the questionnaire on each sub-criteria and criteria.

\subsection{Analysis of results}

As already stated, the aim of this paper is to determine the best site for leisure space in a blighted urban site. The general model process for identifying SZCD is given in Figure 1. The data of this study was analysed in terms of four dimensions: social, economic, built environment and managerial. 12 criteria were used for the analysis, including population density, local history, income, employment, oldness, building density, land-use, value of the land and constructions, quality of constructions, width of passageways, space arrangement, and property value (see Table 1).

\subsubsection{Fuzzy AHP analysis}

After preparing the information layers based on Figure 1, to determine the value of sub-criteria and criteria, FAHP and DANP were used respectively. In this study, based on Buckley (1985) method to express superiority of one sub-criteria over other sub-criteria, linguistic variables (Table 2) were used for expression to form the pairwise comparison matrix.

According to the trapezoidal fuzzy number, representing the corresponding linguistic variable, the pair-wise comparison matrix and calculated weighs of the sub-criteria within "Population Density" (C11) is given in Table 3 as an example.

According to the pair-wise comparison results, the weights of all criteria and sub-criteria were calculated. In order to compare the weights of the criteria and sub-criteria, the fuzzy weight vectors were defuzzified. Thus, the final weight values were ready for use in the GIS environment. 
Table 1. Influence relationship of dimensions and criteria for leisure space performance

\begin{tabular}{|c|c|c|}
\hline $\begin{array}{l}\text { Dimen- } \\
\text { sion }\end{array}$ & Criteria & Explanation \\
\hline \multirow{2}{*}{ 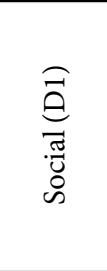 } & $\begin{array}{l}\text { Population } \\
\text { Density } \\
(\mathrm{C} 11) \\
\end{array}$ & $\begin{array}{l}\text { Population density means the population for a level unit and a number of } \\
\text { individuals per hectare. In the study, neighbourhood density is high and amounts } \\
\text { to } 937 \text { people per hectare. }\end{array}$ \\
\hline & $\begin{array}{l}\text { Residence } \\
\text { History } \\
(\mathrm{C} 12)\end{array}$ & $\begin{array}{l}\text { The period of residence from birth or immigration to a particular place is called } \\
\text { residence history. This index can help measure social characteristics such as the rate } \\
\text { of inhabitants belonging to the neighbourhood, the sense of identity, and the level } \\
\text { of participation and empowerment in the design process. }\end{array}$ \\
\hline \multirow{2}{*}{ 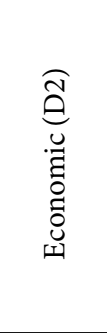 } & $\begin{array}{c}\text { Employ- } \\
\text { ment (C21) }\end{array}$ & $\begin{array}{l}\text { Occupation of major groups of residents in the district show the validity, social } \\
\text { and economic importance and the place in the city as well as neighbourhood } \\
\text { specialization. The general rate of economic activities of the neighbourhood is } \\
32.2 \% \text { with approx. } 28.8 \% \text { employed. }\end{array}$ \\
\hline & $\begin{array}{l}\text { Income } \\
\text { (C22) }\end{array}$ & $\begin{array}{l}\text { Income is the most important indicator for expressing the social and } \\
\text { economic status of a household. Today, income and economic power of a } \\
\text { household determine its place of residence in the city. In the investigated } \\
\text { case, approx. } 55.8 \% \text { of households have the income between } 6 \text { and } 8 \text { million } \\
\text { riyals per month, which also constitutes the largest group of income. }\end{array}$ \\
\hline \multirow{6}{*}{ 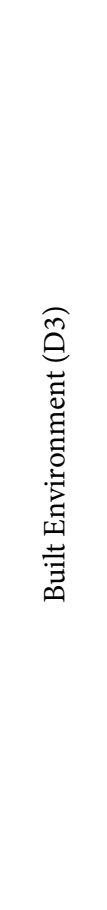 } & $\begin{array}{l}\text { Number of } \\
\text { Floors } \\
\text { (C31) }\end{array}$ & $\begin{array}{l}\text { This criterion include built floors from the foundation to the roof. Buildings located } \\
\text { in the blighted area of Gheytariyeh often have two floors ( } 51 \%) \text {. In the investigated } \\
\text { case, some four-floor buildings were also registered. Most of the commercial street } \\
\text { in Gheytariyeh has buildings with two and almost three floors. In most of them, the } \\
\text { first floor is used for commerce and other floors are residential. Thus, buildings are } \\
\text { often of mixed use, i.e. commercial and residential. }\end{array}$ \\
\hline & $\begin{array}{l}\text { Oldness } \\
\text { (C32) }\end{array}$ & $\begin{array}{l}\text { The age that a building has from the construction date is called oldness. Almost all } \\
\text { buildings in this case ( } 92 \% \text { ) were built until 2012, and their oldness is more than } \\
30 \text { years. }\end{array}$ \\
\hline & $\begin{array}{l}\text { Quality of } \\
\text { Buildings } \\
\text { (C33) }\end{array}$ & $\begin{array}{l}\text { The standard that a building has during its construction is called the quality of } \\
\text { building. Most of the existing buildings in this case are of poor quality and should be } \\
\text { demolished. } 51 \% \text { of buildings should be demolished and } 33 \% \text { should be renovated. }\end{array}$ \\
\hline & $\begin{array}{l}\text { Land-Use } \\
\text { (C34) }\end{array}$ & $\begin{array}{l}\text { In order to study the land-use, it is important to provide basic information about } \\
\text { land features and various important activities. Most buildings are residential use } \\
\text { that allocated } 58.3 \% \text { of the total area and per capita of this usage is estimated } \\
12.8 \mathrm{~m}^{2} \text { for each person. }\end{array}$ \\
\hline & $\begin{array}{l}\text { Building } \\
\text { Density } \\
\text { (C35) }\end{array}$ & $\begin{array}{l}\text { The ratio of the built-over area in a locality is the building density. The average } \\
\text { building density in the area amounts to } 128.5 \% \text {. Many buildings are used for } \\
\text { treatment, with their density amounting to } 250.6 \% \text {; and the least number of } \\
\text { building are used for leisure, with the density amounting to } 0 \% \text {. The density of } \\
\text { buildings use for the residential purpose was } 169.2 \% \text {. }\end{array}$ \\
\hline & $\begin{array}{c}\text { Width of } \\
\text { Passageways } \\
\text { (C36) }\end{array}$ & $\begin{array}{l}\text { The pathways impact on transportation and transit traffic. The width of main } \\
\text { passageways in the neighbourhood amounts to } 3 \text { metres ( } 48 \%), 3 \text { to } 4.5 \text { metres } \\
\text { ( } 37 \% \text { ) and some are } 4.5 \text { metres, but the latter make up a small percentage. }\end{array}$ \\
\hline \multirow{2}{*}{ 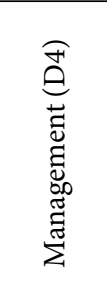 } & $\begin{array}{l}\text { Space } \\
\text { Arrange- } \\
\text { ment }(\mathrm{C} 41)\end{array}$ & $\begin{array}{l}\text { Space arrangement indicates the systematic distribution of buildings in a } \\
\text { neighbourhood and is the direct result of social, economic, political and institutional } \\
\text { processes. In Gheytariyeh, standards of residential, commercial, major and local/ } \\
\text { neighbourhood streets, arterial axis, the neighbourhood centre are considered, as } \\
\text { well as data of JICA and the first zone municipality of Tehran. }\end{array}$ \\
\hline & $\begin{array}{l}\text { Property } \\
\text { Value } \\
(\mathrm{C} 42)\end{array}$ & $\begin{array}{l}\text { The property value can be determined based on the value that is given to standards, } \\
\text { such as architectural, aesthetic, local identity, historic site, cultural site, urban utility } \\
\text { services and related infrastructure. }\end{array}$ \\
\hline
\end{tabular}




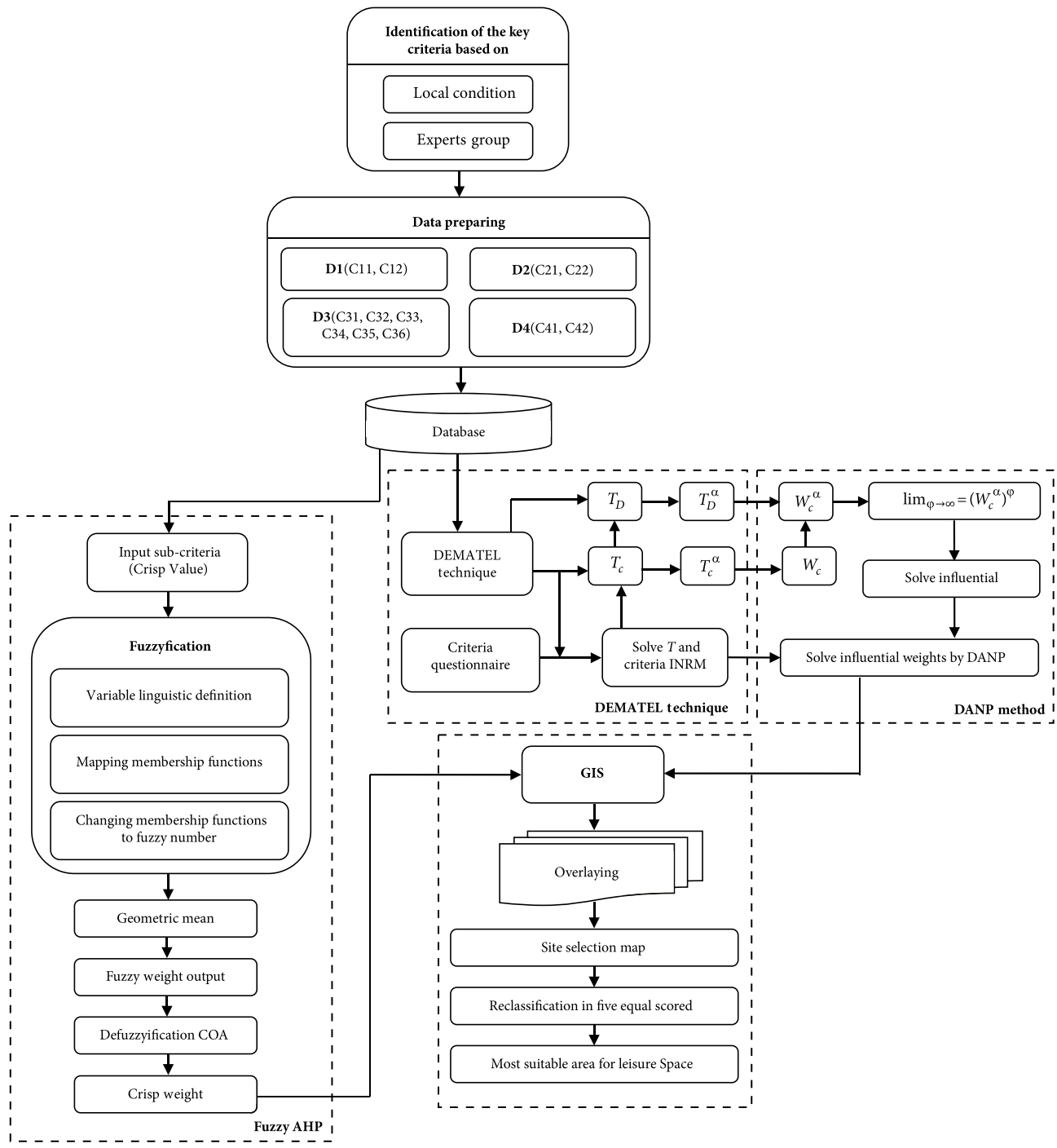

Fig. 1. Integrated approach of SZCD

Table 2. Trapezoidal fuzzy numbers of linguistic variables

\begin{tabular}{cc}
\hline Trapezoidal Fuzzy Numbers (TFN) & Trapezoidal Fuzzy Reciprocal Numbers \\
\hline$(\boldsymbol{L} \boldsymbol{a})$ & $\left(L_{1 / a}\right)$ \\
\hline$(\boldsymbol{a}-\boldsymbol{L} \boldsymbol{b})$ & $\left(1 / a-L_{1 / b}\right)$ \\
\hline$(\boldsymbol{L} \boldsymbol{a}-\boldsymbol{b})$ & $\left(L_{1 / \boldsymbol{a}}-1 / b\right)$ \\
\hline$(\boldsymbol{L} \boldsymbol{a}-\boldsymbol{L} \boldsymbol{b})$ & $\left(L_{1 / \boldsymbol{a}}-L_{1 / b}\right)$ \\
\hline
\end{tabular}


Table 3. Fuzzy AHP-decision matrix and fuzzy weights, Population Density (C11)

\begin{tabular}{ccccccccc}
\hline Class & Person & $0-180$ & $180-580$ & $580-680$ & $680-780$ & $780-980$ & Fuzzy Weight & $\begin{array}{c}\text { Crisp } \\
\text { Weight }\end{array}$ \\
\hline 1 & $0-180$ & $1,1,1,1$ & $4,5,5,6$ & $4,4,5,6$ & $6,6,7,8$ & $6,7,7,8$ & $0.4005,0.4971,0.5937,0.7503$ & 0.5519 \\
\hline 2 & $180-580$ & $1 / 6,1 / 5,1 / 5,1 / 4$ & $1,1,1,1$ & $2,2,3,4$ & $3,4,4,5$ & $4,5,5,6$ & $0.1482,0.1960,0.2354,0.3149$ & 0.2187 \\
\hline 3 & $580-680$ & $1 / 6,1 / 5,1 / 4,1 / 4$ & $1 / 4,1 / 3,1 / 2,1 / 2$ & $1,1,1,1$ & $3,3,4,5$ & $2,2,3,4$ & $0.0851,0.1076,0.1553,0.1916$ & 0.1336 \\
\hline 4 & $680-780$ & $1 / 8,1 / 7,1 / 6,1 / 6$ & $1 / 5,1 / 4,1 / 4,1 / 3$ & $1 / 5,1 / 4,1 / 3,1 / 3$ & $1,1,1,1$ & $1,2,2,3$ & $0.0389,0.0578,0.0699,0.0895$ & 0.0639 \\
\hline 5 & $780-980$ & $1 / 8,1 / 7,1 / 7,1 / 6$ & $1 / 6,1 / 5,1 / 5,1 / 4$ & $1 / 4,1 / 3,1 / 2,1 / 2$ & $1 / 3,1 / 2,1 / 2,1$ & $1,1,1,1$ & $0.0315,0.0444,0.0533,0.0735$ & 0.0495 \\
\hline
\end{tabular}

\subsubsection{The DEMATEL analysis}

For zoning leisure spaces, it is necessary to establish a network of relationships between dimensions and criteria. We adopted the DEMATEL technique to confirm the decisionmaking structural relationship of the evaluation methods and analysed 12 criteria. The experts were asked to determine the importance of the relationships among the criteria. To assess the criteria and measure the average initial direct-relation, $12 \times 12$ matrix $A$ the 0-4 scale were used. This was done by pairwise comparisons in terms of influences and directions between criteria following the DEMATEL technique procedures described in Step 1. By using Eqs (17) and (18), Matrix D (Table 4) shows the normalized direct-relation matrix, which was calculated from Matrix $A$. The total influence matrix $T_{c}$ and the INRM of the relationship between the criteria calculated by Eqs (19), (21) and (22) are shown in Table 5 and Table 6 . It can be seen that all aspects are interdependent.

As shown in Table 6, C34 "land use" is the most important influential regardless of direct and indirect effects. In addition, $C 12$ "local history" is the most influential criteria, as well as the degree $(10.167$ in a total sum $(c+r))$ is the first in the index of strength of influence. C34 "land use" (10.163 in a total sum $(c+r))$ is the second, and C35 "building density" (9.756 in a total sum $(c+r))$ is the third. And $(d-r)$ is the highest in C42 "property values" (1.131 in the total sum $(c-r)$ ), indicating that its direct influence on other criteria is maximal.

Table 4. Normalized direct-influence matrix $D$ for criteria

\begin{tabular}{ccccccccccccc}
\hline$D$ & $C 11$ & $C 12$ & $C 21$ & $C 22$ & $C 31$ & $C 32$ & $C 33$ & $C 34$ & $C 35$ & $C 36$ & $C 41$ & $C 42$ \\
\hline$C 11$ & 0.000 & 0.092 & 0.070 & 0.103 & 0.000 & 0.000 & 0.000 & 0.092 & 0.097 & 0.000 & 0.097 & 0.092 \\
\hline$C 12$ & 0.097 & 0.000 & 0.059 & 0.081 & 0.076 & 0.108 & 0.103 & 0.092 & 0.103 & 0.086 & 0.092 & 0.103 \\
\hline$C 21$ & 0.103 & 0.076 & 0.000 & 0.108 & 0.000 & 0.049 & 0.049 & 0.103 & 0.070 & 0.059 & 0.070 & 0.070 \\
\hline$C 22$ & 0.108 & 0.049 & 0.108 & 0.000 & 0.081 & 0.076 & 0.086 & 0.103 & 0.059 & 0.049 & 0.076 & 0.038 \\
\hline$C 31$ & 0.076 & 0.103 & 0.097 & 0.070 & 0.000 & 0.022 & 0.022 & 0.097 & 0.108 & 0.092 & 0.103 & 0.097 \\
\hline$C 32$ & 0.059 & 0.097 & 0.076 & 0.032 & 0.108 & 0.000 & 0.108 & 0.076 & 0.097 & 0.076 & 0.070 & 0.092 \\
\hline$C 33$ & 0.076 & 0.102 & 0.059 & 0.049 & 0.081 & 0.103 & 0.000 & 0.065 & 0.103 & 0.059 & 0.043 & 0.086 \\
\hline$C 34$ & 0.070 & 0.059 & 0.103 & 0.086 & 0.092 & 0.054 & 0.059 & 0.000 & 0.092 & 0.086 & 0.059 & 0.059 \\
\hline$C 35$ & 0.092 & 0.049 & 0.038 & 0.076 & 0.049 & 0.081 & 0.092 & 0.092 & 0.000 & 0.070 & 0.092 & 0.043 \\
\hline$C 36$ & 0.000 & 0.038 & 0.081 & 0.076 & 0.092 & 0.076 & 0.076 & 0.103 & 0.070 & 0.000 & 0.097 & 0.000 \\
\hline$C 41$ & 0.086 & 0.049 & 0.092 & 0.076 & 0.086 & 0.081 & 0.076 & 0.076 & 0.076 & 0.070 & 0.000 & 0.059 \\
\hline$C 42$ & 0.076 & 0.097 & 0.059 & 0.081 & 0.108 & 0.108 & 0.092 & 0.092 & 0.086 & 0.038 & 0.103 & 0.000 \\
\hline
\end{tabular}


Table 5. Total influence matrix $T_{c}$ for criteria

\begin{tabular}{cccccccccccccc}
\hline$T_{c}$ & $C 11$ & $C 12$ & $C 21$ & $C 22$ & $C 31$ & $C 32$ & $C 33$ & $C 34$ & $C 35$ & $C 36$ & $C 41$ & $C 42$ & $r_{i}$ \\
\hline$C 11$ & 0.277 & 0.334 & 0.332 & 0.365 & 0.243 & 0.244 & 0.247 & 0.393 & 0.386 & 0.221 & 0.372 & 0.318 & 3.732 \\
\hline$C 12$ & 0.493 & 0.381 & 0.456 & 0.474 & 0.436 & 0.458 & 0.457 & 0.546 & 0.545 & 0.410 & 0.508 & 0.447 & 5.612 \\
\hline$C 21$ & 0.405 & 0.357 & 0.305 & 0.406 & 0.279 & 0.320 & 0.323 & 0.447 & 0.407 & 0.304 & 0.387 & 0.333 & 4.273 \\
\hline$C 22$ & 0.437 & 0.364 & 0.432 & 0.334 & 0.372 & 0.363 & 0.376 & 0.478 & 0.431 & 0.320 & 0.420 & 0.332 & 4.657 \\
\hline$C 31$ & 0.432 & 0.429 & 0.445 & 0.426 & 0.321 & 0.342 & 0.345 & 0.503 & 0.498 & 0.379 & 0.473 & 0.401 & 4.994 \\
\hline$C 32$ & 0.423 & 0.436 & 0.431 & 0.395 & 0.430 & 0.327 & 0.427 & 0.489 & 0.500 & 0.372 & 0.450 & 0.407 & 5.088 \\
\hline$C 33$ & 0.413 & 0.417 & 0.392 & 0.384 & 0.383 & 0.398 & 0.308 & 0.452 & 0.476 & 0.336 & 0.401 & 0.381 & 4.741 \\
\hline$C 34$ & 0.400 & 0.368 & 0.424 & 0.411 & 0.381 & 0.344 & 0.353 & 0.383 & 0.454 & 0.352 & 0.406 & 0.345 & 4.622 \\
\hline$C 35$ & 0.399 & 0.342 & 0.349 & 0.381 & 0.330 & 0.353 & 0.365 & 0.443 & 0.351 & 0.322 & 0.412 & 0.316 & 4.363 \\
\hline$C 36$ & 0.297 & 0.310 & 0.368 & 0.358 & 0.349 & 0.329 & 0.333 & 0.428 & 0.391 & 0.245 & 0.393 & 0.257 & 4.056 \\
\hline$C 41$ & 0.416 & 0.363 & 0.417 & 0.403 & 0.379 & 0.370 & 0.368 & 0.455 & 0.444 & 0.339 & 0.351 & 0.349 & 4.655 \\
\hline$C 42$ & 0.460 & 0.455 & 0.439 & 0.456 & 0.448 & 0.441 & 0.431 & 0.525 & 0.512 & 0.355 & 0.498 & 0.341 & 5.360 \\
\hline$c_{i}$ & 4.852 & 4.555 & 4.790 & 4.792 & 4.352 & 4.288 & 4.332 & 5.541 & 5.393 & 3.955 & 5.073 & 4.229 & - \\
\hline & & & & & & & & & & & & &
\end{tabular}

Table 6. Sum of influences given and received for criteria

\begin{tabular}{|c|c|c|c|c|}
\hline Criteria $(i)$ & $\operatorname{sum}\left(c_{i}\right)$ & $\operatorname{sum}\left(r_{i}\right)$ & $c_{i}+r_{i}$ & $c_{i}-r_{i}$ \\
\hline Population Density $C 11$ & 4.852 & 3.732 & 8.585 & -1.120 \\
\hline Residence History C12 & 4.555 & 5.612 & 10.167 & 1.056 \\
\hline Employment C21 & 4.790 & 4.273 & 9.063 & -0.518 \\
\hline Income $C 22$ & 4.792 & 4.657 & 9.450 & -0.135 \\
\hline Number of Floors C31 & 4.352 & 4.994 & 9.346 & 0.643 \\
\hline Oldness C32 & 4.288 & 5.088 & 9.376 & 0.799 \\
\hline Quality of Buildings C33 & 4.332 & 4.741 & 9.073 & 0.409 \\
\hline Land-Use C34 & 5.541 & 4.622 & 10.163 & -0.919 \\
\hline Building Density C35 & 5.393 & 4.363 & 9.756 & -1.030 \\
\hline Width of Passageways C36 & 3.955 & 4.056 & 8.011 & 0.101 \\
\hline Space Arrangement $C 41$ & 5.073 & 4.284 & 9.727 & -0.418 \\
\hline Property Value $C 42$ & 4.229 & 4.925 & 9.589 & 1.131 \\
\hline
\end{tabular}

\subsubsection{Deriving the weights of sub-criteria by DANP}

In this research, after determining the relationship structure between criteria of the leisure spaces through DEMATEL, the ANP method was applied to obtain the weights of each criteria. First, pairwise comparisons were conducted with Saaty's 1-9 scale. The local weights of 12 criteria were obtained through the assessment factors, their respective hierarchical levels and the global weights. An unweighted super-matrix was obtained using Eq. (27) as illustrated in Table 7. A weighted super-matrix based on Eq. (32) was calculated (Table 8). In the next step, we calculated $\lim _{\varphi \rightarrow \infty}=\left(W^{\alpha}\right)^{\varphi}$ to obtain the limit super-matrix (Table 9). The global and local weights of all criteria are presented in Table 10. We used global weights on GIS for the present case. 
Table 7. Unweighted super-matrix

\begin{tabular}{ccccccccccccc}
\hline Unweighted & $C 11$ & $C 12$ & $C 21$ & $C 22$ & $C 31$ & $C 32$ & $C 33$ & $C 34$ & $C 35$ & $C 36$ & $C 41$ & $C 42$ \\
\hline$C 11$ & 0.000 & 1.000 & 1.000 & 1.000 & 0.125 & 0.167 & 0.167 & 1.000 & 1.000 & 0.000 & 1.000 & 0.167 \\
\hline$C 12$ & 0.000 & 0.000 & 0.000 & 0.000 & 0.875 & 0.833 & 0.833 & 0.000 & 0.000 & 0.000 & 0.000 & 0.833 \\
\hline$C 21$ & 0.000 & 0.500 & 0.000 & 1.000 & 0.125 & 0.500 & 1.000 & 0.167 & 0.000 & 0.000 & 0.800 & 0.167 \\
\hline$C 22$ & 0.000 & 0.500 & 1.000 & 0.000 & 0.875 & 0.500 & 0.000 & 0.833 & 0.000 & 0.000 & 0.200 & 0.833 \\
\hline$C 31$ & 0.000 & 0.076 & 0.000 & 0.000 & 0.000 & 0.100 & 0.000 & 0.000 & 0.000 & 0.000 & 0.000 & 0.079 \\
\hline$C 32$ & 0.000 & 0.293 & 0.000 & 0.000 & 0.000 & 0.000 & 0.000 & 0.000 & 0.000 & 0.000 & 0.000 & 0.241 \\
\hline$C 33$ & 0.000 & 0.248 & 0.000 & 0.000 & 0.000 & 0.696 & 0.000 & 0.000 & 0.000 & 0.000 & 0.000 & 0.620 \\
\hline$C 34$ & 1.000 & 0.048 & 0.250 & 0.250 & 0.250 & 0.156 & 0.077 & 0.000 & 1.000 & 0.250 & 0.250 & 0.025 \\
\hline$C 35$ & 0.000 & 0.039 & 0.750 & 0.750 & 0.750 & 0.048 & 0.158 & 1.000 & 0.000 & 0.750 & 0.750 & 0.035 \\
\hline$C 36$ & 0.000 & 0.295 & 0.000 & 0.000 & 0.000 & 0.000 & 0.000 & 0.000 & 0.000 & 0.000 & 0.000 & 0.000 \\
\hline$C 41$ & 0.000 & 0.250 & 0.000 & 1.000 & 0.125 & 0.833 & 1.000 & 0.250 & 1.000 & 1.000 & 0.000 & 1.000 \\
\hline$C 42$ & 0.000 & 0.750 & 0.000 & 0.000 & 0.875 & 0.167 & 0.000 & 0.750 & 0.000 & 0.000 & 0.000 & 0.000 \\
\hline
\end{tabular}

Table 8. Weighting the unweighted super-matrix based on total-influence normalized matrix

\begin{tabular}{ccccccccccccc}
\hline Weighted & $C 11$ & $C 12$ & $C 21$ & $C 22$ & $C 31$ & $C 32$ & $C 33$ & $C 34$ & $C 35$ & $C 36$ & $C 41$ & $C 42$ \\
\hline$C 11$ & 0.000 & 0.440 & 0.224 & 0.208 & 0.029 & 0.039 & 0.039 & 0.234 & 0.286 & 0.000 & 0.088 & 0.012 \\
\hline$C 12$ & 0.000 & 0.000 & 0.000 & 0.000 & 0.204 & 0.195 & 0.195 & 0.000 & 0.000 & 0.000 & 0.000 & 0.058 \\
\hline$C 21$ & 0.000 & 0.029 & 0.000 & 0.120 & 0.023 & 0.091 & 0.181 & 0.030 & 0.000 & 0.000 & 0.122 & 0.020 \\
\hline$C 22$ & 0.000 & 0.029 & 0.129 & 0.000 & 0.158 & 0.091 & 0.000 & 0.151 & 0.000 & 0.000 & 0.030 & 0.100 \\
\hline$C 31$ & 0.000 & 0.031 & 0.000 & 0.000 & 0.000 & 0.046 & 0.000 & 0.000 & 0.000 & 0.000 & 0.000 & 0.048 \\
\hline$C 32$ & 0.000 & 0.118 & 0.000 & 0.000 & 0.000 & 0.000 & 0.349 & 0.000 & 0.000 & 0.000 & 0.000 & 0.145 \\
\hline$C 33$ & 0.000 & 0.101 & 0.000 & 0.000 & 0.000 & 0.317 & 0.000 & 0.000 & 0.000 & 0.000 & 0.000 & 0.373 \\
\hline$C 34$ & 1.000 & 0.020 & 0.162 & 0.150 & 0.114 & 0.071 & 0.035 & 0.000 & 0.557 & 0.195 & 0.190 & 0.015 \\
\hline$C 35$ & 0.000 & 0.016 & 0.485 & 0.451 & 0.342 & 0.220 & 0.072 & 0.456 & 0.000 & 0.584 & 0.570 & 0.021 \\
\hline$C 36$ & 0.000 & 0.120 & 0.000 & 0.000 & 0.000 & 0.000 & 0.000 & 0.000 & 0.000 & 0.000 & 0.000 & 0.000 \\
\hline$C 41$ & 0.000 & 0.024 & 0.000 & 0.069 & 0.016 & 0.000 & 0.129 & 0.032 & 0.158 & 0.221 & 0.000 & 0.208 \\
\hline$C 42$ & 0.000 & 0.072 & 0.000 & 0.000 & 0.113 & 0.022 & 0.000 & 0.097 & 0.000 & 0.000 & 0.000 & 0.000 \\
\hline
\end{tabular}

Table 9. Stable matrix of ANP when power $\lim _{\varphi \rightarrow \infty}=\left(W^{\alpha}\right)^{\varphi}$

\begin{tabular}{ccccccccccccc}
\hline Limit & $C 11$ & $C 12$ & $C 21$ & $C 22$ & $C 31$ & $C 32$ & $C 33$ & $C 34$ & $C 35$ & $C 36$ & $C 41$ & $C 42$ \\
\hline$C 11$ & 0.180 & 0.180 & 0.180 & 0.180 & 0.180 & 0.180 & 0.180 & 0.180 & 0.180 & 0.180 & 0.180 & 0.180 \\
\hline$C 12$ & 0.008 & 0.008 & 0.008 & 0.008 & 0.008 & 0.008 & 0.008 & 0.008 & 0.008 & 0.008 & 0.008 & 0.008 \\
\hline$C 21$ & 0.031 & 0.031 & 0.031 & 0.031 & 0.031 & 0.031 & 0.031 & 0.031 & 0.031 & 0.031 & 0.031 & 0.031 \\
\hline$C 22$ & 0.063 & 0.063 & 0.063 & 0.063 & 0.063 & 0.063 & 0.063 & 0.063 & 0.063 & 0.063 & 0.063 & 0.063 \\
\hline$C 31$ & 0.002 & 0.002 & 0.002 & 0.002 & 0.002 & 0.002 & 0.002 & 0.002 & 0.002 & 0.002 & 0.002 & 0.002 \\
\hline$C 32$ & 0.012 & 0.012 & 0.012 & 0.012 & 0.012 & 0.012 & 0.012 & 0.012 & 0.012 & 0.012 & 0.012 & 0.012 \\
\hline$C 33$ & 0.018 & 0.018 & 0.018 & 0.018 & 0.018 & 0.018 & 0.018 & 0.018 & 0.018 & 0.018 & 0.018 & 0.018 \\
\hline$C 34$ & 0.344 & 0.344 & 0.344 & 0.344 & 0.344 & 0.344 & 0.344 & 0.344 & 0.344 & 0.344 & 0.344 & 0.344 \\
\hline$C 35$ & 0.241 & 0.241 & 0.241 & 0.241 & 0.241 & 0.241 & 0.241 & 0.241 & 0.241 & 0.241 & 0.241 & 0.241 \\
\hline$C 36$ & 0.001 & 0.001 & 0.001 & 0.001 & 0.001 & 0.001 & 0.001 & 0.001 & 0.001 & 0.001 & 0.001 & 0.001 \\
\hline$C 41$ & 0.065 & 0.065 & 0.065 & 0.065 & 0.065 & 0.065 & 0.065 & 0.065 & 0.065 & 0.065 & 0.065 & 0.065 \\
\hline$C 42$ & 0.034 & 0.034 & 0.034 & 0.034 & 0.034 & 0.034 & 0.034 & 0.034 & 0.034 & 0.034 & 0.034 & 0.034 \\
\hline
\end{tabular}


Table 10. Influential weights and relative importance of criteria

\begin{tabular}{lcc}
\hline \multicolumn{1}{c}{ Dimension/Criteria } & Local weight (based on DANP) & Global weight (based on DANP) \\
\hline Social $(\boldsymbol{D 1})$ & $\mathbf{0 . 1 8 9}$ & 0.180 \\
\hline Population Density $(C 11)$ & 0.956 & 0.008 \\
\hline Residence History $(C 12)$ & 0.044 & 0.031 \\
\hline Economic $(\boldsymbol{D} 2)$ & $\mathbf{0 . 0 9 4}$ & 0.063 \\
\hline Employment $(C 21)$ & 0.330 & \\
\hline Income $(C 22)$ & 0.670 & 0.002 \\
\hline Built Environment $(\boldsymbol{D} 3)$ & $\mathbf{0 . 6 1 8}$ & 0.012 \\
\hline Number of Floors $(C 31)$ & 0.004 & 0.018 \\
\hline Oldness $(C 32)$ & 0.020 & 0.344 \\
\hline Quality of Buildings $(C 33)$ & 0.028 & 0.241 \\
\hline Land-Use $(C 34)$ & 0.557 & 0.001 \\
\hline Building Density $(C 35)$ & 0.390 & 0.065 \\
\hline Width of Passageways $(C 36)$ & 0.002 & 0.034 \\
\hline Management $(\boldsymbol{D 4})$ & $\mathbf{0 . 0 9 9}$ & \\
\hline Space Arrangement $(C 41)$ & 0.653 & \\
\hline Property Value $(C 42)$ & 0.347 & \\
\hline
\end{tabular}

\subsection{Site selection}

In order to identify the planning factors of SZCD, we prepared a base map for the criteria and sub-criteria. Then, by using field observations and the Statistic Centre of Iran data, the maps were updated. Then the vector layers were converted to raster because the raster has more ability to show easiness and portray processing for modelling tasks and different map integration. Finally, fuzzy values for each layer, criteria and sub-criteria were applied and identified.

Each of the layers were classified separately and divided to sub-criteria. The importance rate of sub-criteria was obtained by FAHP values. The resulting map of this classification is shown in Figure 2.

An important point of this research is the importance of precision in determining the related values to each criteria that has an important role for final results and the output plan. If the values are determined carefully, research results are closer to facts and have a higher reliability. This closeness occurs when the relationships between criteria are specified correctly and this is done by experts. This point is always considered at all stages of research.

A GIS-based MCDM was used for selection of leisure space in ArcGIS. The final map for the best leisure space in the blighted site is shown in the Figure 3. Overlapping layers were classified into five classes: ideal, favourable, relatively favourable, less favourable and unfavourable.

The ideal area of $2662.9 \mathrm{~m}^{2}$ was selected for leisure spaces (5.5\% of the total area). The selected sites are located in the western part of area, close to the intersection of three streets Saba Boulevard, Gheytariyeh St. and Karimi St. $32.8 \%$ of the selected total area 
Population density (C11)

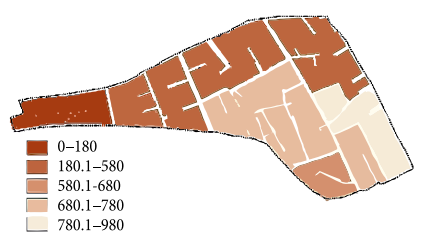

Income (C22)

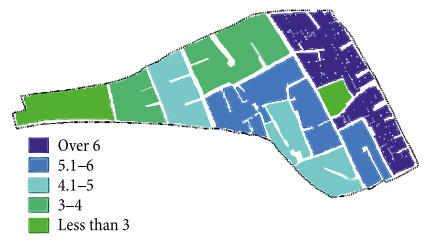

Building quality (C33)

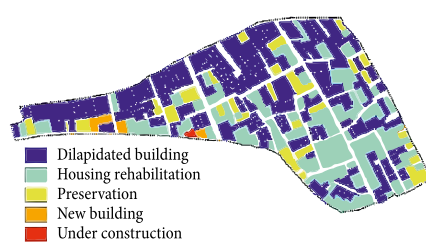

Pavement width (C36)

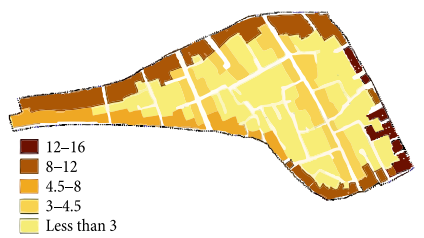

Residence history (C12)

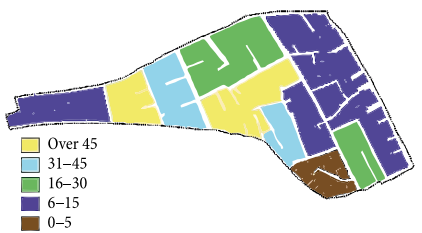

Floor quantity (C31)

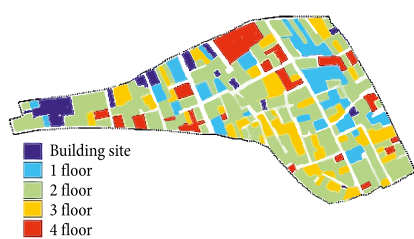

Land use (C34)

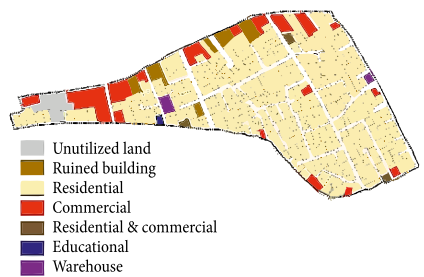

Space organization (C41)

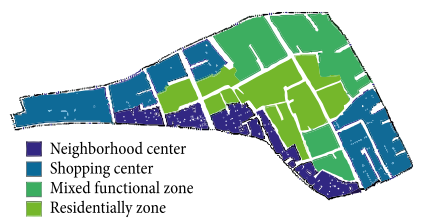

Employment (C21)

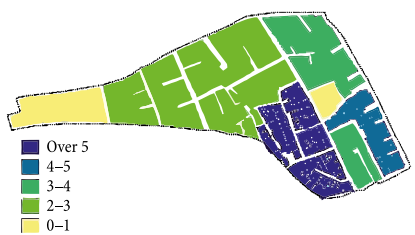

Oldness (C32)

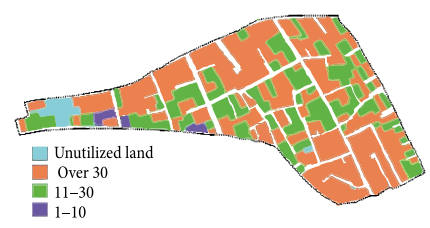

Building density (C35)

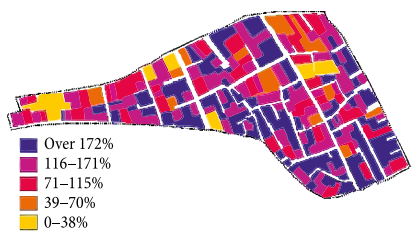

Property values (C42)

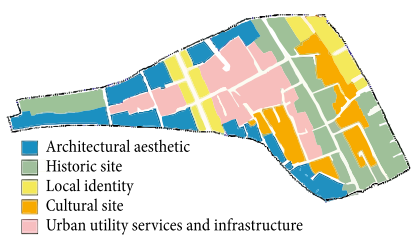

Fig. 2. Maps as input data layers of sub-criteria used for the proposed Fuzzy AHP model

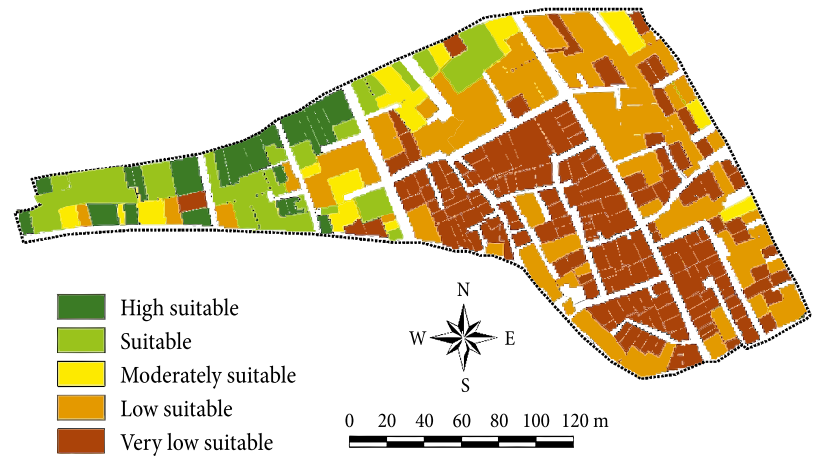

Fig. 3. Final map for the best leisure space in the blighted site 
planned for leisure spaces is for residential use, $42.3 \%$ of commercial use, $17.8 \%$ is ruined and uninhabited, and $7.1 \%$ is unutilized. $38.9 \%$ of this space has the density of 147 people per hectare, and $61.1 \%$ has the density of 147 to 581 people per hectare. In any case, this figure is superior compared with the Gheytariyeh Zone (173.3 people per hectare) and is more of a high-class zone.

In the north of this area, there are arterial passageways of the second grade. The area is use as collection and distribution area. In this sense, it has an effective role in connecting inlet and outlet area for integration and social participation.

\section{Conclusions}

In the last few decades, leisure spaces became one of the vital necessities of human societies and one of important concerns of planners and managers. Leisure spaces provide more welfare and comfort for citizens. Planning processes of leisure spaces requires a comprehensive review, flexibility and appropriate indicators for the prediction of the required land, distribution and the coordination between different types of use.

To comply with these requirements and to resolve related issues; we require the participation of individuals with different views and interests. One of group decision support tools is a multi-criteria decision-making with fuzzy approach that could increase the reciprocal effect and participation of people in decision-making.

Used together with GIS, these tools are used for urban planning while making decisions on the type of use of an urban site as well as provide a possibility for the selection of a suitable urban site. Here, uncertainty and complexity of the real world provides more flexibility to the use of GIS based on fuzzy logic. The method also provides a probability of representation of imprecise meaningful concepts. Decision support is the ultimate goal of GIS. GIS capabilities for spatial decision support are analysed in three main stages of the decision-making process: knowledge, design and selection.

This study propose a new hybrid model of SZCD based on MCDM in GIS environment. The purpose is to select the best site for leisure space. This hybrid is used to get a weight of sub-criteria and identify relationships of dependence among various criteria. We used FAHP to determine the weights of sub-criteria for the site selection decision process. Then DEMATEL was applied to build INRM that illustrates influential networks of dimensions and criteria of leisure space. The results show the interrelations between dimensions and criteria, also influential priorities and the most important sequences of those. Finally, this study employed DANP to obtain the weight of each criteria and attain the selection of leisure site by GIS, based on INRM from the DEMATEL method.

\section{Acknowledgements}

We would like to express our gratitude to Prof. Jafar Jafari of the University of WisconsinStout, USA for useful comments and suggestions, as well as support and encouragement during the study. We are grateful to Dr. Aliakbar Jafari of the University of Strathclyde, UK for valuable comments and suggestions to the final version. The authors would also like to express their gratitude to the experts at both the Tehran Municipality and the University of Tehran. 


\section{References}

Buckley, J. J. 1985. Fuzzy hierarchical analysis, Fuzzy Sets and Systems 17(3): 233-247. http://dx.doi.org/10.1016/0165-0114(85)90090-9

Chen, C.-T.; Lin, C.-T.; Huang, S.-F. 2006. A fuzzy approach for supplier evaluation and selection in supply chain management, International Journal of Production Economics 102(2): 289-301. http://dx.doi.org/10.1016/j.ijpe.2005.03.009

Chen, F.-H.; Hsu, T.-S.; Tzeng, G.-H. 2011. A balanced scorecard approach to establish a performance evaluation and relationship model for hot spring hotels based on a hybrid MCDM model combining DEMATEL and ANP, International Journal of Hospitality Management 30(4): 908-932. http://dx.doi.org/10.1016/j.ijhm.2011.02.001

Chen, S.-J. J.; Hwang, C.-L.; Beckmann, M. J.; Krelle, W. 1992. Fuzzy multiple attribute decision making: methods and applications. New York: Springer-Verlag, Inc. http://dx.doi.org/10.1007/978-3-642-46768-4

Chen, Y.-C.; Lien, H.-P.; Tzeng, G.-H. 2010. Measures and evaluation for environment watershed plans using a novel hybrid MCDM model, Expert Systems with Applications 37(2): 926-938. http://dx.doi.org/10.1016/j.eswa.2009.04.068

Cheng, T.-M.; Tsaur, S.-H. 2012. The relationship between serious leisure characteristics and recreation involvement: A case study of Taiwan's surfing activities, Leisure Studies 31(1): 53-68. http://dx.doi.org/10.1080/02614367.2011.568066

Craig, L.; Mullan, K. 2012. Shared parent-child leisure time in four countries, Leisure Studies 31(2): 211-229. http://dx.doi.org/10.1080/02614367.2011.573570

Daftaribesheli, A.; Ataei, M.; Sereshki, F. 2011. Assessment of rock slope stability using the Fuzzy Slope Mass Rating (FSMR) system, Applied Soft Computing 11(8): 4465-4473. http://dx.doi.org/10.1016/j.asoc.2011.08.032

Dumazedier, J.; McClure, S. E. 1967. Toward a society of leisure. New York: Free Press.

Fontela, E.; Gabus, A. 1976. The DEMATEL Observer, DEMATEL 1976 Report. Battelle Geneva Research Center, Geneva, Switzerland.

Gabus, A.; Fontela, E. 1972. World problems, an invitation to further thought within the framework of DEMATEL. Battelle Geneva Research Center, Geneva, Switzerland.

Genoe, M. R. 2010. Leisure as resistance within the context of dementia, Leisure Studies 29: 303-320. http://dx.doi.org/10.1080/02614361003720570

Gudienė, N.; Banaitis, A.; Podvezko, V.; Banaitienė, N. 2014. Identification and evaluation of the critical success factors for construction projects in Lithuania: AHP approach, Journal of Civil Engineering and Management 20(3): 350-359. http://dx.doi.org/10.3846/13923730.2014.914082

Harinen, P. M.; Honkasalo, M. V.; Ronkainen, J. K.; Suurpää, L. E. 2012. Multiculturalism and young people's leisure spaces in Finland: perspectives of multicultural youth, Leisure Studies 31(2): 177191. http://dx.doi.org/10.1080/02614367.2011.576427

Henderson, K. A. 2007. Quality of life and leisure education: Implications for tourism economies, World Leisure Journal 49(2): 88-93. http://dx.doi.org/10.1080/04419057.2007.9674489

Heo, E.; Kim, J.; Boo, K.-J. 2010. Analysis of the assessment factors for renewable energy dissemination program evaluation using fuzzy AHP, Renewable and Sustainable Energy Reviews 14(8): 2214-2220. http://dx.doi.org/10.1016/j.rser.2010.01.020

Horng, J.-S.; Liu, C.-H.; Chou, S.-F.; Tsai, C.-Y. 2013a. Creativity as a critical criterion for future restaurant space design: developing a novel model with DEMATEL application, International Journal of Hospitality Management 33: 96-105. http://dx.doi.org/10.1016/j.ijhm.2012.06.007

Horng, J.-S.; Liu, C.-H.; Chou, S.-F.; Tsai, C.-Y. 2013b. Professional conceptions of creativity in restaurant space planning, International Journal of Hospitality Management 34: 73-80.

http://dx.doi.org/10.1016/j.ijhm.2013.02.006 
Hsu, C.-H.; Wang, F.-K.; Tzeng, G.-H. 2012. The best vendor selection for conducting the recycled material based on a hybrid MCDM model combining DANP with VIKOR, Resources, Conservation and Recycling 66: 95-111. http://dx.doi.org/10.1016/j.resconrec.2012.02.009

Hsueh, S.-L.; Lee, J.-R.; Chen, Y.-L. 2013. DFAHP multicriteria risk assessment model for redeveloping derelict public buildings, International Journal of Strategic Property Management 17(4): 333-346. http://dx.doi.org/10.3846/1648715X.2013.852995

Iphar, M.; Goktan, R. 2006. An application of fuzzy sets to the Diggability Index Rating Method for surface mine equipment selection, International Journal of Rock Mechanics and Mining Sciences 43(2): 253-266. http://dx.doi.org/10.1016/j.ijrmms.2005.07.003

Karsak, E. E.; Sozer, S.; Alptekin, S. E. 2003. Product planning in quality function deployment using a combined analytic network process and goal programming approach, Computers \& Industrial Engineering 44(1): 171-190. http://dx.doi.org/10.1016/S0360-8352(02)00191-2

Kaya, I.; Kahraman, C. 2014. A comparison of fuzzy multicriteria decision making methods for intelligent building assessment, Journal of Civil Engineering and Management 20(1): 59-69. http://dx.doi.org/10.3846/13923730.2013.801906

Konlaan, B.; Theobald, H.; Bygren, L. 2002. Leisure time activity as a determinant of survival: a 26-year follow-up of a Swedish cohort, Public Health 116(4): 227-230. http://dx.doi.org/10.1016/s0033-3506(02)90071-5

Lee, H.; Kim, M.-S.; Park, Y. 2012. An analytic network process approach to operationalization of five forces model, Applied Mathematical Modelling 36(4): 1783-1795.

http://dx.doi.org/10.1016/j.apm.2011.09.012

Lee, W.-S.; Tu, W.-S. 2011. Combined MCDM techniques for exploring company value based on Modigliani-Miller theorem, Expert Systems with Applications 38(7): 8037-8044. http://dx.doi.org/10.1016/j.eswa.2010.12.138

Lin, Y.-Y.; Pan, N.-H. 2014. Multi period performance assessment model for the site property management, International Journal of Strategic Property Management 18(4): 332-343. http://dx.doi.org/10.3846/1648715X.2014.970596

Liou, J. J. 2012. Developing an integrated model for the selection of strategic alliance partners in the airline industry, Knowledge-Based Systems 28: 59-67. http://dx.doi.org/10.1016/j.knosys.2011.11.019

Liou, J. J.; Wang, H.; Hsu, C.; Yin, S. 2011. A hybrid model for selection of an outsourcing provider, Applied Mathematical Modelling 35(10): 5121-5133. http://dx.doi.org/10.1016/j.apm.2011.04.020

Liu, C.-H.; Tzeng, G.-H.; Lee, M.-H. 2012. Improving tourism policy implementation - The use of hybrid MCDM models, Tourism Management 33(2): 413-426.

http://dx.doi.org/10.1016/j.tourman.2011.05.002

McFadzean, E. 1998. Enhancing creative thinking within organisations, Management Decision 36(5): 309-315. http://dx.doi.org/10.1108/00251749810220513

Mentes, A.; Helvacioglu, I. H. 2012. Fuzzy decision support system for spread mooring system selection, Expert Systems with Applications 39(3): 3283-3297. http://dx.doi.org/10.1016/j.eswa.2011.09.016

Moeinaddini, M.; Khorasani, N.; Danehkar, A.; Darvishsefat, A. A. 2010. Siting MSW landfill using weighted linear combination and analytical hierarchy process (AHP) methodology in GIS environment (case study: Karaj), Waste Management 30(5): 912-920. http://dx.doi.org/10.1016/j.wasman.2010.01.015

Peng, K.-H.; Tzeng, G.-H. 2013. A hybrid dynamic MADM model for problem-improvement in economics and business, Technological and Economic Development of Economy 19(4): 638-660. http://dx.doi.org/10.3846/20294913.2013.837114

Pieper, J. 2009. Leisure: the basis of culture. The philosophical act. Ignatius Press.

Pourahmad, A.; Hosseini, A.; Nasiri, H. 2012. Strategies for improving leisure spaces position with an emphasis on urban regeneration: a case study of Ghaytarieh Neighborhood, Tehran, in A. Zainal, 
S. Radzi, R. Hashim, C. Chik, R. Abu (Eds.). Current issues in hospitality and tourism: research and innovations. CRC Press. http://dx.doi.org/10.1201/b12752-101

Rabbiosi, C. 2015. Renewing a historical legacy: tourism, leisure shopping and urban branding in Paris, Cities 42(Part B): 195-203.

Reshmidevi, T.; Eldho, T.; Jana, R. 2009. A GIS-integrated fuzzy rule-based inference system for land suitability evaluation in agricultural watersheds, Agricultural Systems 101(1): 101-109. http://dx.doi.org/10.1016/j.agsy.2009.04.001

Richards, G. 2011. Creativity and tourism: the state of the art, Annals of Tourism Research 38(4): 12251253. http://dx.doi.org/10.1016/j.annals.2011.07.008

Ross, T. J. 2009. Fuzzy logic with engineering applications. John Wiley\&Sons.

Saaty, T. L. 1980. The analytic hierarchy process: planning, priority setting, resources allocation. New York: McGraw-Hill.

Saaty, T. L. 1996. Decision making with dependence and feedback: the analytic network process. Pittsburgh: RWS Publications.

Sánchez-Lozano, J. M.; Teruel-Solano, J.; Soto-Elvira, P. L.; Socorro García-Cascales, M. 2013. Geographical Information Systems (GIS) and Multi-Criteria Decision Making (MCDM) methods for the evaluation of solar farms locations: case study in south-eastern Spain, Renewable and Sustainable Energy Reviews 24: 544-556. http://dx.doi.org/10.1016/j.rser.2013.03.019

Shen, Y.-C.; Lin, G. T.; Tzeng, G.-H. 2011. Combined DEMATEL techniques with novel MCDM for the organic light emitting diode technology selection, Expert Systems with Applications 38(3): 14681481. http://dx.doi.org/10.1016/j.eswa.2010.07.056

Sicat, R. S.; Carranza, E. J. M.; Nidumolu, U. B. 2005. Fuzzy modeling of farmers' knowledge for land suitability classification, Agricultural Systems 83(1): 49-75. http://dx.doi.org/10.1016/j.agsy.2004.03.002

Stebbins, R. 2013. Unpaid work of love: defining the work-leisure axis of volunteering, Leisure Studies 32(3): 339-345. http://dx.doi.org/10.1080/02614367.2012.667822

Sternberg, R. J. 2006. The nature of creativity, Creativity Research Journal 18(1): 87-98. http://dx.doi.org/10.1207/s15326934crj1801_10

Sun, C.-C. 2010. A performance evaluation model by integrating fuzzy AHP and fuzzy TOPSIS methods, Expert Systems with Applications 37(12): 7745-7754. http://dx.doi.org/10.1016/j.eswa.2010.04.066

Tan, S.-K.; Luh, D.-B.; Kung, S.-F. 2014. A taxonomy of creative tourists in creative tourism, Tourism Management 42: 248-259. http://dx.doi.org/10.1016/j.tourman.2013.11.008

Tan, Y.; Shen, L.-Y.; Langston, C. 2014. A fuzzy approach for adaptive reuse selection of industrial buildings in Hong Kong, International Journal of Strategic Property Management 18(1): 66-76. http://dx.doi.org/10.3846/1648715X.2013.864718

Thibault, A. 2011. A new era for World Leisure's partnership with UNESCO, World Leisure Journal 53(4): 340-343. http://dx.doi.org/10.1080/04419057.2011.630796

Torkildsen, G. 2005. Leisure and recreation management. Psychology Press. http://dx.doi.org/10.4324/9780203401651

Tsai, W.-H.; Chou, W.-C. 2009. Selecting management systems for sustainable development in SMEs: a novel hybrid model based on DEMATEL, ANP, and ZOGP, Expert Systems with Applications 36(2): 1444-1458. http://dx.doi.org/10.1016/j.eswa.2007.11.058

Tsai, W.-H.; Kuo, H.-C. 2011. Entrepreneurship policy evaluation and decision analysis for SMEs, Expert Systems with Applications 38(7): 8343-8351. http://dx.doi.org/10.1016/j.eswa.2011.01.022

Van Holm, E. J. 2014. Leisure choices of the creative class, Cities 41: 38-43. http://dx.doi.org/10.1016/j.cities.2014.05.006

Wang, Y.-M.; Elhag, T.; Hua, Z. 2006. A modified fuzzy logarithmic least squares method for fuzzy analytic hierarchy process, Fuzzy Sets and Systems 157(23): 3055-3071.

http://dx.doi.org/10.1016/j.fss.2006.08.010 
Willemse, L.; Donaldson, R. 2012. Community Neighbourhood Park (CNP) use in Cape Town's townships, Urban Forum 23(2): 221-231.

Wong, S.; Pang, L. 2003. Motivators to creativity in the hotel industry-perspectives of managers and supervisors, Tourism Management 24(5): 551-559. http://dx.doi.org/10.1016/S0261-5177(03)00004-9

Wu, W.-W.; Lee, Y.-T. 2007. Developing global managers' competencies using the fuzzy DEMATEL method, Expert Systems with Applications 32(2): 499-507. http://dx.doi.org/10.1016/j.eswa.2005.12.005

Yazdani-Chamzini, A. 2014. An integrated fuzzy multi criteria group decision making model for handling equipment selection, Journal of Civil Engineering and Management 20(5): 660-673. http://dx.doi.org/10.3846/13923730.2013.802714

Zavadskas, E. K.; Turskis, Z.; Kildienè, S. 2014. State of art surveys of overviews on MCDM/MADM methods, Technological and Economic Development of Economy 20(1): 165-179. http://dx.doi.org/10.3846/20294913.2014.892037

Zheng, G.; Zhu, N.; Tian, Z.; Chen, Y.; Sun, B. 2012. Application of a trapezoidal fuzzy AHP method for work safety evaluation and early warning rating of hot and humid environments, Safety Science 50(2): 228-239. http://dx.doi.org/10.1016/j.ssci.2011.08.042

\begin{abstract}
Ahmad POURAHMAD. Professor at the Department of Geography and Urban Planning at the University of Tehran and Head of the Department of Geography and Tourism Planning at Kish International Campus of the University of Tehran. His research encompasses the areas of urban geography, urban blight and tourism. He is also the editor-in-chief and co-editor for research on geography and urban planning at the University of Tehran and other universities in Iran.
\end{abstract}

Ali HOSSEINI received his $\mathrm{PhD}$ (2015), BS (2009) and a MS (2011) degrees in human geography and urban planning from the University of Tehran. His research interests are concerned with spatial planning, urban planning, multiple criteria decision making and quantitative methods. He has published papers and book chapters in several international and national journals.

Audrius BANAITIS. Professor at the Department of Construction Economics and Property Management of Vilnius Gediminas Technical University. His research interests include project/risk management and project success, property management, sustainability and construction industry development, multiple criteria decision making: applications in construction and real estate.

Hossein NASIRI. PhD student of human geography at the University of Tehran. He received his MS on Remote Sensing \& GIS (2011) and BS in physical geography (2008) form the University of Tehran. His research interests include spatial analysis and decision-making.

Nerija BANAITIENĖ. Associate Professor at the Department of Construction Economics and Property Management of Vilnius Gediminas Technical University. Her research interests include project/risk management, total quality management, building life cycle analysis, multiple criteria decision making: applications in construction and real estate.

Gwo-Hshiung TZENG is a National Distinguished Chair Professor and Distinguished Research Fellow of the National Taipei University, Taiwan. He received his Bachelor's degree in Business Management from the Tatung Institute of Technology (1967); Master's degree in Urban Planning from Chung Hsing University (1971); and PhD in Management Science from Osaka University, Japan (1977). He is EditorIn-Chief of the International Journal of Operations Research and the International Journal of Information Systems for Logistics and Management, among others. He is a member of IEEE, IAEE, ISMCDM, World Transport, etc. His current research interests include statistics, multivariate analysis, networks, routing and scheduling, multiple criteria decision making, fuzzy theory, hierarchical structure analysis for application to technology management, energy, environment, transportation systems, transportation investment, logistics, location, urban planning, tourism, technology management, electronic commerce, and global supply chains. 